\title{
ISLAMISASI PSIKOLOGI
}

\author{
Iin Tri Rahayu
}

\begin{abstract}
.
Islamization of psychology, in fact, is the effort to meet between Islamic doctrines and theories of psychology, or an effort how to explain psychological problem in the way of Islamic perspective. To achieve this purpose, there are two methods: pragmatism and idealism.

Pragmatism method is an effort to appear Islamic psychology by giving priority on practice realization; adopted theories of western psychology, which has been establish, then searching for legitimating from the sacred text both al-Qur'an and hadits. In other side, idealism method is an effort to develop Islamic psychology based on the teaching and resources of Islamic knowledge itself. Furthermore, the theories of Islamic psychology that have been resulted is compared to the western psychology theories.
\end{abstract}

Keywords: Psychology, Western, and Islam.

Al-Faruqi berpendapat bahwa islamisasi sains harus dimulai dari sintesis antara ilmu pengetahuan modern dengan Islam. Zaiuddin Sardar tidak sependapat dengan gagasan Faruqi tersebut. Menurutnya, islamisasi sains musti dimulai dari hal-hal yang paling mendasar, yaitu dari pandangan dunia (world view) Islam dan paradigma Islam sendiri. ${ }^{1}$

Menurut Djamaludin Ancok, pengembangan psikologi Islam bermula dari ide dan gerakan islamisasi sains yang dipelopori oleh dua orang tokoh tersebut. Berkaitan dengan islamisasi psikologi, berdasarkan pemikiran Faruqi, apa yang dimaksud psikologi Islam berarti harus dimulai dari penemuan dan teori-teori psikologi Barat yang sudah mapan. Konsekuensinya; pertama, psikologi dipakai sebagai pisau analisis terhadap masalah-masalah kejiwaan umat Islam, dan kedua, Islam dijadikan sebagai pisau analisis untuk menilai konsep-konsep psikologi Barat. Sebaliknya, mengikuti Sardar, psikologi Islam harus dibangun dari kerangka pikir (mode of thought) Islam sendiri. Ini bisa terjadi, karena dalam nash terdapat sejumlah informasi mengenai persoalan-persoalan substansial psikologi, misalnya al-fitrah, al-rruh, al-nafsh, al-qalb, al-dhamir, dan sebagainya. ${ }^{2}$

\section{Jejak Psikologi Islam.}

Islam tidak saja menawarkan sistem kepercayaan, peribadatan dan etika, tetapi lebih jauh, Islam juga mencakup seluruh kebudayaan dan peradaban, termasuk kebudayaan dan peradaban ilmiah. Karena itu, pertanyaan yang meragukan adanya teori-teori psikologi dalam Islam berarti menunjukkan keawaman penanyanya. Dalam rentang sejarah kebudayaan dan peradaban, wacana Islam tidak pernah sunyi dari pembahasan psikologi, mulai dari prinsipprinsip dasar, konsep-konsep fisiologis, sampai pada teknik operasionalnya.

Pada zaman nabi Muhammad SAW, wacana psikologi Islam masih berupa prinsip-prinsip dasar (mabadi'). Prinsip-prinsip dasar ini terakumulasi di dalam wahyu yang kebenarannya bersifat mutlak dan permanen, baik berupa al-Qur'an 
maupun al-Sunnah. Segala persoalan psikologis telah tuntas dijawab oleh Nabi Muhammad SAW, meski belum masuk pada masalah-masalah teknik operasional. Namun, hal itu tidak berarti bahwa Nabi Muhammad SAW tidak memahami fenomena psikologis yang empiris-eksperimental, melainkan semata-mata karena memberikan kebebasan seluas-luasnya kepada umatnya untuk berijtihad. Sabdanya engkau lebih mengetahui urusan duniamu memberikan sinyalemen agar umat Islam berupaya melakukan eksperimentasi terhadap fenomena-fenomena psikologis, agar prinsip-prinsip dasar Islam di dalam wahyu dapat terjabarkan secara empiris. ${ }^{3}$

Pada masa keemasan Islam, terutama pada khalifah Abbasiyah, para psikolog-falsafi dan psikolog-sufistik banyak menyumbangkan konsep-konsep spekulatif-filosofis mengenai psikologi, seperti konsep tentang jiwa, baik menyangkut tentang potensi, perkembangan, penyakit maupun terapinya. Selain menggali sumber jiwa dari nash, mereka juga melakukan perenungan (ta'ammul) secara sistematis, radikal dan universal, bahkan ada diantaranya yang telah melakukan pendekatan empiris, meski belum mewakili corak pemikiran di masanya. Hal itu didiasarkan atas kenyataan bahwa perkembangan psikologi spekulatif dari Persia dan Yunani telah mewarnai pemikiran hampir seluruh umat manusia. Karena itu, mereka berusaha melakukan hal yang sama dengan cara melakukan pendekatan filosofis terhadap nash mengenai persoalan-persoalan psikologis, sehingga diakui atau tidak, dunia Islam telah menyumbangkan konsepkonsep psikologi yang cukup berarti.

Bersamaan dengan kemunduran pemikiran Islam abad XIV, dunia Barat mulai bangkit dan mengambil alih semangat keilmuan yang berasal dari Islam. Studi yang mereka kembangkan melaju dengan cepat dan berkelanjutan, bahkan pada pertengahan abad XVIII muncul studi yang bersifat empiris yang didakwahkan sebagai kemunculan psikologi modern. Meskipun teori-teori mereka banyak bermanfaat bagi kehidupan umat manusia, namun disadari atau tidak, banyak teori-teori mereka yang bertentangan dengan konsepsi dasar Islam. Karena itu, para pemerhati, peneliti, penulis, psikolog muslim bangkit dari tidurnya. Mereka melakukan gerakan islamisasi psikologi untuk mensucikan dan mengembalikan kejayaan psikologi seperti masa lalu. Upaya yang dilakukan bukan sekedar mengungkapkan konsep-konsep spekulatif psikologi, melainkan juga memasuki pendekatan empiris-eksperimental.

Teori-teori tentang Psikologi Islam lambat laun bermunculan, meskipun sebagian psikolog memberikan komentar yang bervariatif. Sebagian psikolog menganggap Psikologi Islam sebagai diskursus yang pra-ilmiah atau pseudo ilmiah, sebagian lain menganggapnya sudah memenuhi persyaratan ilmiah.

\section{Pengertian Psikologi Islam.}

Secara etimologi psikologi memiliki arti "ilmu tentang jiwa". Dalam bahasa Arab, istilah "jiwa" disamakan dengan al-nafs atau al-ruh, sehingga psikologi dapat diterjemahkan ke dalam bahasa Arab menjadi ilmu al-nafs atau ilmu al-ruh. Secara terminologis, psikologi Islam dapat dirumuskan sebagai kajian Islam yang berhubungan dengan aspek-aspek dan perilaku kejiwaan manusia agar 
secara sadar ia dapat membentuk kualitas diri yang lebih sempurna dan mendapatkan kebahagiaan di dunia dan akhirat. ${ }^{4}$

Definisi tersebut mengandung tiga unsur pokok. Pertama, psikologi Islam merupakan salah satu dari kajian masalah-masalah keislaman yang memiliki kedudukan yang sama dengan disiplin ilmu keislaman lain, seperti ekonomi Islam, politik Islam dan sebagainya. Penempatan kata Islam di sini memiliki arti corak, cara pandang, pola pikir, paradigma atau aliran. Artinya, psikologi Islam adalah psikologi yang dibangun berdasarkan corak atau memiliki pola pikir sebagaimana yang berlaku pada tradisi kelimuan dalam Islam, sehingga membentuk aliran tersendiri yang berbeda dengan psikologi pada umumnya.

Kedua, psikologi Islam membicarakan aspek-aspek dan perilaku kejiwaan manusia yang dalam Islam dikenal dengan istilah al-ruh, al-nafs, al-qalb, al-'aql, al-dhamir, al-lubb, al-fu'ad, al-sirr, al-fitrah dan sebagainya. Masing-masing aspek tersebut memiliki eksistensi, dinamika, proses, fungsi dan perilaku yang perlu dikaji melalui al-Quran, al-Sunnah serta khazanah pemikiran Islam. Psikologi Islam tidak hanya menekankan perilaku kejiwaan melainkan juga hakikat jiwa sesungguhnya. Sebagai satu organisasi permanen, jiwa manusia bersifat potensial yang aktualisasinya dalam bentuk perilaku sangat tergantung pada daya upayanya.

Ketiga, psikologi Islam bukan netral etik melainkan sarat akan nilai etik, karena Islam memiliki tujuan tersendiri, yaitu merangsang kesadaran diri agar mampu membentuk kualitas diri yang lebih sempurna untuk mendapatkan kebahagiaan hidup di dunia dan akhirat. Manusia dilahirkan dalam kondisi tidak mengetahui apa-apa, lalu tumbuh dan berkembang untuk mencapai kualitas hidup. Psikologi Islam merupakan salah satu disiplin yang membantu seseorang untuk memahami ekspresi diri, aktualisasi diri, realisasi diri, konsep diri, cira diri, harga diri, kesadaran diri, kontrol diri dan evaluasi diri baik untuk diri sendiri maupun untuk diri orang lain. ${ }^{5}$

\section{Paradigma Psikologi Islam}

Pemunculan paradigma psikologi Islam merupakan hal yang baru, bahkan bisa dikatakan sebagai reaksi dari kemajuan diskursus psikologi Barat. Reaksi itu semakin memuncak setelah munculnya banyak benturan-benturan akibat psikologi Barat yang antroposentis dan netral etik dijadikan sebagai pisau analisis dalam memahami fenomena psikologis masyarakat Islam yang teosentris dan sarat etik.

Upaya pemetaan metode dan pendekatan psikologi Islam harus ditopang oleh suatu paradigma yang mapan. Pemikiran ini didasarkan atas asumsi bahwa suatu disiplin ilmu tidak akan bernilai obyektif apabila tidak didasarkan atas paradigma-paradigma yang mapan berikut asumsi-asumsinya. Karena itu, penelusuran paradigma ini merupakan kerja awal yang harus diselesaikan terlebih dahulu sebelum melangkah ke arah penyusunan substansi psikologi Islam. Paradigma psikologi Islam harus dihubungkan dengan pemikiran filosofis dalam Islam. Setidaknya ada dua kelompok yang berbeda berkaitan dengan kerangka dasar paradigma psikologi Islam ini.

1. Kelompok yang mengehendaki keterbukaan terhadap pandangan hidup dan kehidupan non muslim. Kelompok ini berusaha mengadopsi konsep-konsep 
psikologi non Islam dan menggabungkannya ke dalam pemikiran psikologi Islam

2. Kelompok yang berusaha mengangkat pesan besar Ilahi ke dalam pemikiran psikologi, baik dari al-Qur'an, Sunnah maupun penafsiran ulama terhadap kedua sumber tersebut. ${ }^{6}$

Kelompok pertama didasarkan atas asumsi bahwa tidak ada salahnya jika pemikir muslim meminjam atau bahkan menemukan kebenaran dari pihak lain. Rasul sendiri menyatakan, Hikmah itu merupakan barang yang hilang, jika ditemukan darimana saja datangnya, maka ia berhak memilikinya, (HR. Turmudzi). Hadits ini memberikan sinyalemen agar pemikir muslim tidak segansegan mengadopsi pemikiran non Islam, dengan catatan bahwa pemikiran tersebut mengandung suatu kebenaran. Adapun dasar dari pemikiran kelompok kedua adalah bahwa Islam merupakan sistem ajaran yang universal dan komprehensif. Tak satupun persoalan termasuk persoalan psikologis yang luput dari jangkauan ajaran Islam. Firman Allah, Tiadalah Kami alpakan sesuatupun di dalam alKitab, kemudian kepada Tuhanlah mereka dihimpunkan (QS. al-An'am, 38). Dan Kami turunkan kepadamu al-Kitab (al-Qur'an) untuk menjelaskan segala sesuatu dan petunjuk serta rahmat dan kabar gembira bagi orang-orang yang berserah diri (QS. al-Nahl, 89). Dua ayat di atas memberi isyarat bahwa konsep dasar psikologi Islam telah ada daam sumber otentik Islam, al-Qur'an dan hadits.

\section{Metode Pengembangan.}

Metode pengkajian dan pengembangan psikologi Islam dapat ditempuh melalui dua cara, yaitu metode pragmatis dan idealistik.

Metode pragmatis adalah metode pengkajian dan pengembangan psikologi Islam yang lebih mengutamakan aspek praktis dan kegunaannya. Untuk itu, bangunan psikologi Islam dapat diadopsi dan ditransformasikan dari kerangka teori-teori dan psikologi Barat yang sudah mapan. Teori-teori tersebut kemudian dicarikan legalitasnya dari nash atau diupayakan pentazkiyah-an sehingga kesimpulannya bernuansakan Islami. Metode ini akan menghasilkan rumusan yang lazim disebut dengan "Psikologi Islami".

Langkah-langkah operasionalnya yang dapat ditempuh sebagaimana yang ditawarkan al-Faruqi, adalah:

1. Penguasaan disiplin ilmu modern dan penguraian kategoris.

2. Survai disiplin ilmu pengetahuan

3. Penguasaan khazanah Islam, sebuah ontologis.

4. Penguasaan khazanah ilmiah Islami, tahap analisis

5. Penemuan relevansi Islam yang khas terhadap disiplin-disiplin ilmu pengetahuan.

6. Penilaian kritis terhadap disiplin ilmu modern, tingkat perkembangannya di masa ini.

7. Penilaian kritis terhadap khazanah Islam, tingkat perkembangan dewasa ini.

8. Survai permasalahan yang dihadapi umat Islam.

9. Survai permasalahan yang dihadapi umat manusia

10. Analisis kreatif dan sintesis

11. Penuangan kembali disiplin ilmu modern ke dalam kerangka Islam 
12. Penyebarluasan ilmu-ilmu yang telah diislamisasikan. ${ }^{7}$

Pada pertengahan abad XIX, psikologi Barat lahir sebagai disiplin ilmu yang mandiri dan sampai saat ini telah memunculkan beberapa cabang dan aliran. Cabang-cabang dalam psikologi adalah (a). Psikologi Umum, yang menyelidiki dan mempelajari kegiatan-kegiatan atau aktivitas-aktivitas psikis manusia yang tercermin tingkah laku pada umumnya, dan (b) psikologi khusus yang menyelidiki dan mempelajari segi-segi kekhususan dari aktivitas-aktivitas psikis manusia, yaitu antara lain Psikologi Perkembangan, Psikologi Sosial, Psikologi Pendidikan, Psikologi Kepribadian, Psikopatologi, Psikologi Kriminologi, Psikologi Perusahaan dan sebagainya. Adapun aliran-aliran dalam psikologi, secara garis besar dapat dikelompokkan menjadi tiga, yaitu (a) psikoanalisis, (b) behavioristik, dan (c) humanistik. Masing-masing aliran tersebut memiliki kerangka berpikir yang berbeda dalam bangunan teorinya. ${ }^{8}$

Melalui metode pragmatis, teori-teori yang ada dapat dimasukkan ke dalam keutuhan psikologi Islam setelah diadakan eliminasi dan pengkudusan. Upaya ini bukan sekedar mengadakan interpretasi adaptif, tetapi lebih jauh, ia berfungsi sebagai pemahaman sunnah-sunnah Allah, penjabaran universalitas Islam serta upaya operasionalisasinya agar misi Islam sebagai rahmah li al'alamin dapat terwujud. Kelebihan metode pragmatis ini adalah responsif, akomodatif dan toleran terhadap perkembangan sains modern, khususnya pada disiplin psikologi. Metode ini sangat efektif dan efisien untuk membangun disiplin baru dalam psikologi Islami, sebab ia tidak beranjak dari pemikiran yang kosong. Namun boleh jadi metode ini membawa psikologi Islami ke arah frame sekuler yang menyalahi kode etik ilmiah Qurani. Kekhawatiran itu sangat mungkin karena paradigma yang digunakan adalah psikologi Barat yang berbeda dengan paradigma Islam, apalagi proses adopsi tidak melalui proses seleksi yang ketat, sehingga sulit dibedakan antara psikologi yang bercorak Islam dengan psikologi yang bercorak sekuler.

Hanna Djumhana mengatakan bahwa metode ini menghasilkan enam pola, yaitu: (1). Pola similarisasi, yaitu menyamakan begitu saja konsep-konsep sains dengan konsep-konsep yang berasal dari Islam, padahal belum tentu sama. Misalnya menganggap sama antara al-ruh dengan spirit, al-nafs dengan soul, dan ilham dengan inspirasi, (2). Pola paralelisasi, yaitu menganggap paralel konsep yang berasal dari Islam dengan konsep yang berasal dari sains karena kemiripan konotasi, tanpa mengidentikkan keduanya. Misalnya perang Dunia III disamakan dengan kiamat; (3) pola komplementasi, yaitu antara Islam dan sains saling mengisi, dan saling memperkuat, tetapi tetap mempertahankan eksistensinya masing-masing. Misalnya manfaat puasa secara kesehatan yang dijelaskan dengan konsep diet; (4). pola komparasi, yaitu membandingkan konsep atau teori sains dengan Islam mengenai gejala-gejala yang sama. Misalnya teori motivasi dalam psikologi dibandingkan dengan motivasi dalam Islam; (5). Pola induktifikasi, yaitu asumsi-asumsi dasar dan teori-teori ilimiah yang didukung oleh temuantemuan empirik dilanjutkan pemikirannya secara teoritis-abstrak ke arah pemikiran metafisik atau ghaib, kemudian dihubungkan dengan Maha Rabb Allah; (6). Pola verifikasi, yaitu mengungkapkan hasil-hasil penelitian ilmiah 
yang menunjang dan membuktikan kebenaran ajaran Islam. Misalnya fungsi madu sebagai obat yang dihubungkan dengan surat QS. al-Nahl, 69.

Meode idealistik adalah metode yang lebih mengutamakan penggalian psikologi Islam dari ajaran Islam sendiri. Metode ini menggunakan pola deduktif dengan cara menggali premis mayor sebagai postulat yang digali dari nash. Konstruksi premis mayor ini dijadikan sebagai "kebenaran universal" yang dijadikan kerangka acuan penggalian premis minor. Melalu metode ini maka terciptalah apa yang disebut dengan "Psikologi Islam".

Ziauddin Sardar secara rinci telah memberikan kerangka epistimologis dalam menerapkan metode idealistik ini yang dituangkan dalam sembilan konstruksi, yaitu:

1. Didasarkan atas suatu kerangka pedoman mutlak, sebab datangnya dari Tuhan dan rasul-Nya.

2. Bersifat aktif dan bukan pasif.

3. Memandang obyektifitas sebagai masalah umum dan bukan masalah khusus (pribadi).

4. Sebagian besar bersifat deduktif.

5. Memadukan pengetahuan dengan nilai-nilai Islam.

6. Memandang pengetahuan bersifat inklusif dan bukan eksklusif, yakni menganggap pengalaman manusia sebagai masalah subyektif yang sama validitasnya dengan evolusi yang bersifat obyektif.

7. Menyusun pengalaman subyektif dan mendorong pencaharian pengalamanpengalaman ini, yang dari umat Islam sendiri diperoleh komitmen-komitmen nilai dasar mereka.

8. Memadukan konsep-konsep dari tingkat kesadaran (imajinatif-kreatif) dengan tingkat pengalaman subyektif (mistik-spiritual), sehingga konsep-konsep dan kiasan-kiasan yang sesuai dengan satu tingkat tidak harus sesuai dengan tingkat yang lain.

9. Tidak bertentangan dengan pandangan Holistik, melainkan menyatu dan manusiawi dari pemahaman dan pengalaman manusia. Dengan demikian, epistemologi Islam sesuai dengan pandangan yang lebih menyatu dari perkembangan pribadi dan pertumbuhan intelektual.

Dalam bahasa yang berbeda, Hanna Djumhana telah merumuskan tujuh prinsip berpikir ilmiah-Qur'ani, yaitu:

1. Empiris-metaempiris;

2. Rasional-intuitif

3. Obyektif-partisipatif;

4. Absolutisme moral berpijak pada prinsip keunikan sistem;

5. Eksplisit mengungkap kemampuan spiritual;

6. Aksioma diturunkan dari ajaran agama; dan

7. Pendekatan holistik menurut modal manusia seutuhnya, baru kemudian mengadakan parsialisasi ke bidang disiplin.

Kerangka epistemologi di atas menantang para peneliti, pengkaji maupun pemerhati psikologi Islam untuk menggali kembali khazanah yang pernah dimilikinya, sehingga apa yang disebut psikologi Islam benar-benar dapat terwujud secara aktual dan sarat nilai Islam [.] 


\section{Catatan Akhir.}

${ }^{1}$ Hoodbhoy, P, Islam dan Sains Pertarungan Menegakkan Rasionalitas, (Bandung: Pustaka, 1997), 96-97

2 Djamaluddin Ancok, "Pengantar" dalam Fuad Nashori (ed), Membangun Paradigma Psikologi Islam, (Yogyakarta: Sipress, 1994), x.

${ }_{3}$ Mujib, A. Mudzakir, J. Nuansa-Nuansa Psikologi Islam. (Jakarta: Raja Grafindo Persada, 2001), xiii-xv.

${ }^{4}$ Ibid, 3-7.

${ }_{6}^{5}$ Ibid, 12

${ }^{6}$ Abd al-Rahman Salih, "Educational Theory a Quranic Outlook, (Makkah: Umm alQura University, 1982), 35-36.

${ }^{7}$ Mujib, A. Mudzakir, Nuansa-Nuansa Psikologi Islam, 15-23

${ }^{8}$ Walgito, B, Pengantar Psikologi Umum, (Yogyakarta: Andi Offset, 1990), 19-20.

9 Bastaman, H.D, Integrasi Psikologi dengan Islam, Menuju Psikologi Islami., (Yogyakarta: Pustaka Pelajar, 1995), 32.

\section{DAFTAR PUSTAKA}

Bastaman, H.D. 1995. Integrasi Psikologi dengan Islam, Menuju Psikologi Islami. Pustaka Pelajar. Yogyakarta.

Hoodbhoy, P. 1997. Islam dan Sains Pertarungan Menegakkan Rasionalitas. Pustaka. Bandung.

Mujib, A. Mudzakir, J. 2001. Nuansa-Nuansa Psikologi Islam. Raja Grafindo Persada. Jakarta.

Nashori, F. 1994. Membangun Paradigma Psikologi Islam. Sipress. Yogyakarta.

Walgito, B. 1990. Pengantar Psikologi Umum. Andi Offset. Yogyakarta 